\title{
Diplomacy or War as First Recourse: Panacea of the AU Roadmap for Libya
}

\author{
Nte Timothy Ubelejit $(\mathrm{PhD})$ \\ Department of Political and Administrative Studies University of Port Harcourt, Nigeria
}

\begin{abstract}
International relation is viewed in the dual perspective of cooperation and conflict while diplomacy and war are the instruments for this relationship or foreign policy. Nevertheless in contemporary international relations, nations politely engage in diplomacy and eschew war as reciprocity is expected. More so, war has been prohibited as an instrument of foreign policy as evident in the Kellogg-Briand Pact and the United Nations Charter. Oblivious of this fact the African Union (AU) attempted to diplomatically mediate the crisis that engulfed Libya. Unfortunately the diplomatic overture of the AU was ignored by Western Forces who declared war on Libya. The article weighs the options of diplomacy and war with a view to determining what should come first. Is it the diplomatic efforts of the AU through the Roadmap for Libya or the declaration of war by Allied Forces? The article concludes that to forestall plunging the world back into the era of brazen imperialistic barbarism that war should remain the last recourse. It suggest that in consonance with Article 33 of the UN Charter parties to a dispute that might endanger peace should first seek a resolution through negotiation, inquiry, mediation, conciliation, arbitration, judicial settlement, resort to regional agencies etc.
\end{abstract}

Keywords: Diplomacy, War, First, Recourse, Roadmap

\section{Introduction}

The African Union in particular and indeed a great majority of Africans in general are alleging that the invasion of Libya was not in the interest of Africans. They allege that the AU was ignored in the handling of the crisis in Libya which began in the month of February 2011 as part of the Arab Spring Uprisings. The African Union designed a roadmap, which would have extensively used diplomacy to douse the tension and crisis in Libya but Western forces ignored this option and declared war on Libya. The neglect and near contempt of Africa in the invasion of Libya is one too many of the marginalization and naked exploitation of the weakness of Africa and Africans.

You would recall that the Arab Spring Uprisings began in the form of agitations for reforms and internal uprisings which began in Tunisia and spread to Egypt, Libya, Yemen, Syria and Qatar. The Libyan crisis started with pockets of protest for a feel of democracy in the Benghazi region with minor demonstrations. According to Cogan (2011) "Operations by the Libyan armed forces to suppress their small-scale uprising were exaggerated by the major powers into genocidal blood-letting against civilians that could be prevented only by foreign military intervention."

Fair enough the issue of humanitarian intervention to save the population of Libya from the slaughter of Muammar Gaddafi was presented to the United Nations. This gave birth to United Nations Security Council Resolution 1973. The terms of this resolution was clearly spelt out. It was passed to enforce a no-fly zone and protect Libyan civilians. The United Nations Security Council Resolution 1973 was enacted when it was obvious that Resolution 1970 was not serving the purpose of protecting the opposition of the Gaddafi regime. Resolution 1970, according to Shah (2011) "was designed to call for restraint and to report any human rights abuses to the International Criminal Court (ICC). Resolution 1973 was passed by the UNSC in March 2011 to authorise a no-fly zone for the protection of civilians."

Protection of civilians from the onslaught of Muammar Gaddafi through a no-fly zone imposition and other pacific mediation methods was the original idea when Resolutions 1970 and 1973 was enacted. Apparently the three African countries (Nigeria, South Africa and Gabon) sitting as non-permanent members of the United Nations Security Council endorsed their consents for these Resolutions because they didn't suspect "hidden triggers". This was not the case for countries like Russia, China, Brazil, Germany and India who abstained. Their wealth of experiences, mostly in the Iraqi case, has made them to be wary of resolutions with undertones.

In the case of Iraq, Resolution 1441 was meant for the setting of a new timetable and a new, enhanced regime of inspections that would monitor the disarmament of Iraq. This resolution was eventually misinterpreted and used to invade Iraq. According to Normand (2003) "It is the height of hypocrisy for the U.S. and U.K. to base war on Resolution 1441 when they are fully aware that France, Russia and China approved that resolution on explicit written condition that it could not be used by individual states to justify military action," 
Evidently the invasion of Libya did not follow the due process of allowing enough room for diplomacy and using war as a last recourse as proposed by the roadmap of the African Union. Resolution 1973 was manipulated to serve some vested imperial interest. Jacob Zuma "highlighted allegations by Russia, China, India and his country that NATO's airstrikes in Libya had breached UN resolutions." This is more so, when the African Union was not carried along in the Libyan invasion decisions and actions. As reported by Gadugah (2011) "The African Union feels completely ignored by World bodies in the quest to restore peace in conflict ridden Libya, the AU commission chairman Jean Ping has said."

The security arrangements for a country or region should carry the region along in terms of perception and issues. It should have answers to questions that border on conscientious reconciliation that would genuinely reconcile the factions amicably. The question here is what is the best approach to handle a crisis that would give room to genuine reconciliation? Is it diplomacy or war? To this we turn.

\section{Diplomacy Or War As First Recource To Crisis}

Diplomacy and war are both instruments of foreign policy. "If world politics is identified as being the interplay between conflict and cooperation, then, war and diplomacy can be said to represent the two defining institutions" [Ghosh 2009] Nevertheless in contemporary international system nations politely engage in diplomacy and eschew aggression or outright war on other states as reciprocity is expected. An essential ingredient in international relations is diplomacy. According to Starke J. G. in "the past, more often than not, disputes led to war but nowadays States shrink from so drastic a culmination of their controversies, and if the dispute cannot be resolved, more usually a rupture of trade or diplomatic relations ensures."

The UN Charter directs in Article 33 that parties to a dispute that might endanger peace should first "seek a resolution through negotiation, inquiry, mediation, conciliation, arbitration, judicial settlement, resort to regional agencies or arrangements, or other peaceful means of their choice." [Umozurike 2001] Brute force or savage declaration of war is a barbaric act that is alien to the contemporary international order and age of globalization where diplomacy and corporation between nations is the trend.

Diplomacy is the underlying word in international relations for friends and adversaries. According to Harold Nicolson "Diplomacy is the agency through which foreign policy seeks to attain its purpose by agreement rather than by war" The focal point of diplomacy is the prevention of disputes degenerating into war. This is by negotiation, dialogue and other pacific resolution of dispute methods. "Diplomacy entirely involves direct government-to-government interactions so that a particular state can persuade governments in their countries to act in the manner in which it wants them to do." [Ghosh 2009]

On the other hand, war is one of the perennial proclivities of human existence and international relations. Communities, states and nations have constantly engaged in warfare as an instrument of conducting foreign policy, acquisition of power, imperialism, control of hegemony etc. Although there has been the great desire of man to leave peacefully without war and/or limit the extent of war, it inevitably periodically occurs. According to Hunt (2008) "war is often regarded as inevitable and many states seem to prefer peace only when it comes from their enemies complete submission".

This has been the case from time immemorial and war has continued to be a horrendous genocide to the lives and civilizations of mankind at the expense of peace and collective development. As recorded by Raaflaub (2007) "The historian of ancient law Sir Henry Maine, famously remarked that 'War appears to be as old as mankind, but peace is a modern invention."

One definition of war that to a reasonable extend captures the invasion of Libya was that of Karl von Clausewitz who is one of the early classical writers that recognized the use of war to achieve national goals and objectives. According to Clausewitz (1976) "War is a continuation of commerce... by other means." He noted that "War is an instrument of policy: it must necessarily bear its character, it must measure with its scale; the conduct of War, in its great features, is therefore policy itself, which takes up the sword in place of the pen, but does not on that account cease to think according to its own laws." [ibid]

The primary feature of war is that it has a certain state of organized violent conflict that is engaged in between two or more separate social entities. Leaders, sometimes declare war under the impression that their actions are primarily defensive, unfortunately when critically analysed a disillusionment of unprovoked, unwarranted, or disproportionate aggression emanates and this has been taken place over the years.

Happily war as an instrument of foreign policy has been prohibited by Kellogg-Briand Pact and the United Nations Charter. The Kellogg Briand Pact is a treaty for the renunciation of war as an instrument of National Policy. "The Kellogg Briand Pact was signed on August 27, 1928 and entered into force on July 24 $1929 \ldots$ the Kellogg Briand Pact condemn recourse to war for the solution of their international controversies, and renounced it as an instrument of national policy in their relations with one another."'Arent and Beck 1996] It was also agreed in the Kellogg Briand Pact that "the settlement or solution of all disputes or conflicts of whatever nature or of whatever origin they may be, which may arise among them, shall never be sought except by peaceful means." ibid 
The African Union was subtly and tactfully using diplomacy to negotiate for peace in Libya. An essential element of diplomacy is adequate potentials to combine the stick and the carrot which the AU was harnessing, for the peaceful resolution of the crisis. Considering the herculean task of negotiating with Gaddafi and his forces the Allied Forces should have added weight to the carrot and stick that is requisite for effective diplomatic outcome instead of blatant declaration of war. Obviously a combination of diplomacy and coercive diplomacy of the international community as a whole would have saved the situation.

Enough time would have been given to weigh the success or failure of the normal diplomacy and to progressively intensify intervention through coercive diplomacy if the conventional diplomacy fails. Coercive diplomacy has to do with credible threats that would achieve enumerated goals. According to George (1991) coercive diplomacy is "persuasion backed with credible threats" to achieve set goals. This is buttressed by Art and Cronin (2003) who says that "Coercive diplomacy has as one of its essential features, and often its only feature, the threat or limited use of force". In a similar vein, Lake (2001) says coercive diplomacy is "the use of threatened force to induce an adversary to behave differently than it otherwise would". Tarzi (2006) noted that "ultimately the utility of coercion is embedded in achieving national objectives without coercion actually being used". Coercive diplomacy is different from pure coercion and involves bargains, negotiations, and compromises as well as coercive threats. The summary of it all is that coercive diplomacy is the act of using threats, forceful persuasion and other coercive acts (short of full blown war) to achieve set goals and targets.

Cases abound in international relations were coercive diplomacy is used by nations to achieve or compel a goal or set target. Although recently made more coherent and tangible by Alexander George the ideas and practice of coercive diplomacy has been known and applied more than two thousand five hundred years ago. As far back as 500BC Sun Tzu declared that "to subdue the enemy without fighting is the acme of skill". This is inherently referring to coercive diplomacy.

Although diplomacy is sometimes ineffective for recalcitrant African leaders as demonstrated by the 2010 elections in Ivory Coast when Allacene Oauttara won Lauren Gbagbo (the incumbent President) coercive diplomacy is a more effective tool. More so, in this age when war is no longer an instrument of foreign policy, declaration of war tantamount to two wrongs making a right, which is an anathema.

Despite the well articulated, highly effective and generally accepted treaties regulating the use of force and diplomatic approaches to the settlement of conflicts; some advanced countries are not following the due process but apparently twisting the treaties to achieve their ulterior goals as evident in Libya. "Every proposal for a negotiated end to the war that has been issued by the African powers, Italy, or Russia has been met with new US-NATO provocations. The allied powers are clearly determined to sabotage any diplomatic manoeuvres that cut across their agenda." [O'Connor 2011]

They are evidently taking advantage of the weakness of Africa in particular and Third World countries in general to exploit and control resources. This was the case with Iraq and Libya. In Libya Roadmap of Africa to follow the diplomatic overtures prominent in the United Nations Charter was sidelined. What is the nature of the roadmap of the African Union to the Libyan crisis? To this we turn

\section{The Roadmap Of Au In The Libyan Crisis}

The response and approach of the African Union to the mediation of the Libyan crisis can best be evaluated in cognizance of the Arab Spring Uprisings generally. In Tunisia and Egypt it took its natural shape despite the intrinsic coercion to protect constituted authorities. The human rights of the protesters may have been infringed on to protect the interest of an overwhelming majority of the population. Nevertheless issues that border on the forceful change of regime by force are inimical to the founding principles of the African Union. "The guiding principles for the AU were the Lomé Declaration on Unconstitutional Changes in Government (2000) and the Constitutive Act of the African Union (2002), which prohibited unconstitutional changes in government." [Dewaal 2011]

Obviously there were no caveats or exception to the rule as the drafters of the Constitutive Act of the African Union did not foresee the kind of revolts that manifested in the form of the Arab Spring Uprisings. It would be recalled that the African Union (AU) was "formed in 2000, with the aim of developing and integrating Africa, the AU aims to assist Africa to transform into a prosperous and stable continent commanding more respect on the international stage. [Madlala 2011]

Just as we have vast and varied people, cultures, creed, colour and language so we do have peculiar problems for the different regions of the world. Issues in Europe should best be handled by the European Union and if it is beyond their scope international organizations would seek their consent and opinion on what to do. This was not the case for Africa because the invasion of Libya was not supported by the African Union. "Yet, lasting peace on the continent can only be achieved if efforts to that end are based on the full involvement of Africa...because we understand the problems far better; because we know which solutions will work and because, fundamentally, these problems are ours, and our peoples will live with their consequences." [Jean Ping 2011]. The Chairman of the African Union further stated that "Asserting Africa's leadership will also require 
that, as highlighted by the PSC ..., we do not shrink from decisive actions to overcome the challenges confronting the continent; that there is no conflict on the continent that will be considered to be out of bounds for the African Union..."

Humanity is no longer in the era when brazen imperialistic barbarism confronted it as war is now seen as a last recourse a step taken after exhaustive negotiations, arbitration and conciliation. That was the reasoning of the African Union and indeed Africans in the quest to resolve the crisis that beseeched Africa. This is also what informed the African Union "to play a mediating role in Libya, advocating a cease-fire but opposing foreign intervention...’'[Madlala 2011]

This is subscribed to by Jean Ping who notes that "Our ultimate objective was to avoid war. As a regional organisation, diplomacy is our main weapon and the use of force is always a last resort when all other options have been exhausted." He went further to state that "In Libya, as in other countries affected by the "Arab Spring', the AU based its action on the need to contribute to the achievement of the overall objectives sought by the union, namely peace, stability, democratic governance, respect for human rights, justice, prosperity and unity." It is for this reason that as early as 23 February, the Peace and Security Council (PSC) expressed its deep concern over developments in Libya, strongly condemning the indiscriminate and excessive use of force against peaceful demonstrators. It also underscored the legitimacy of the aspirations of the Libyan people. [ibid]

Civilized settlement of disputes holds diplomacy and other pacific measures in high esteem. Negotiation which is the greatest attribute of diplomacy must carry the people of the region along. Surely you have to negotiate with the people who are involved in the dispute and so the country or region should be carried along in terms of perception and issues. It is only through the negotiations that issues like true reconciliation that would heal wounds and suppress vendetta is achieved. The use of force to achieve a goal normally breeds resentment and vengeance even at suicidal levels which makes the whole exercise counterproductive.

The position of the African Union to exhaustively use diplomacy to settle the crisis should have been respected. This becomes more pertinent with the realization that "The fate of the Libyan people is inseparable from that of the rest of their African brothers and sisters, with whom they have historical ties...an unstable Libya will first and foremost affect its African neighbourhood and beyond." [Dewaal 2011]

The agenda of some Western countries is to intervene in African states in particular and Third World states in general to consolidate and actualize economic and geo-strategic imperial interests. According to Chipaike (2012) "the real ambitions of NATO were not simply protecting civilians from the savage that Gaddafi was but to lay their hands on Libya's oil, which they have already done, and to get profitable reconstruction contracts."

It is also for this reason that the negotiations and diplomatic moves of the African Union to mediate and bring the crisis to an end without shading more blood were blocked by the Western forces. "The blocking of the AU diplomatic initiative indicates that the decision to escalate the military intervention beyond the defence of Benghazi to an agenda of regime change, could not be justified as a last resort. There were options for a negotiated settlement that could have been pursued."[op cit]

This is in sharp contrast to the African Peace and Security Council approach which took account of the real challenges which encompasses immediate issues and long-term outcomes. "They were driven by a genuine commitment to do whatever was possible to facilitate dialogue among Libyans, ensure that they owned any solution to the crisis, avoid further suffering and create conditions conducive to a smooth and peaceful transition. The AU was also aware of the risks that continued fighting in Libya posed to regional stability and security." [ibid]

In a meeting of the African Union a panel was constituted to oversee the accomplishment of the 'roadmap' to peace in Libya. "The AU panel presented an African roadmap for peace which included an immediate cease-fire, an end to NATO bombings, a truce between the rebels and Gaddafi's forces which would be supervised by the international community and negotiations between the rebels and Gaddafi to reach a political settlement." [Burns 2011] It was meant to engage the rival factions in Libya and evaluate the true position of things. The panel also sought to pave way for the implementation of the political reforms that necessitated the uprisings in Libya and amicable mediation of the crisis.

This was the background for the "roadmap" and the appointment of a panel to oversee the accomplishment of the aims and objectives. The panel consists of reputable African leaders like: President Jacob Zuma of South Africa, President of the Republic of Congo Sassou Nguessou, President AmadouToumani Toure of Mali, and Ugandan President YoweriMuseveni. The panel according to [Xuequan 2011] "was established with the sole objective of engaging with the parties involved and mediating a peaceful dialogue between them to resolve the conflict."

It was a formidable diplomatic force because the personalities wielded the required clout for a negotiated settlement devoid of war with all its complexities, tremendous casualties and massive destruction of properties. "The AU's principal diplomatic advantage was that only African leaders could make the case to 
Gaddafi... with any credibility. A combination of African access to Gaddafi and NATO leverage over the TNC could have provided the basis for a negotiated settlement. [ibid]

The position that Africans were not carried along in their collective security with particular reference to the invasion of Libya was most aptly captured by Yoweri Museveni, the Ugandan President. As reported by Abati (2011), in the New Vision, Ugandan state-owned newspaper, Museveni protested undue intervention in African affairs saying that: "I am totally allergic to foreign, political and military involvement in sovereign countries, especially African countries. This according to him is because 'The Western countries always use double standards. In Libya, they are very eager to impose a no-fly zone. In Bahrain and other areas where there are pro-Western regimes, they turn a blind eye to the very same conditions or even worse conditions." Museveni feels that what goes on in Africa is selective intervention to explore and exploit the resources of Africa. This explains the reason why despite all the upheavals in Somalia the West is not intervening. Museveni asked: "Are there no human beings in Somalia similar to the ones in Benghazi? Or is it because Somalia does not have oil which is not fully controlled by the Western oil companies?" [ibid]

The same position of seeking African solution to African problems or carrying Africans along in security efforts in their territory was shared by other African Heads of State. Mauritanian President Ould Abdel Aziz decried any foreign military intervention in Libya. Aziz added that any solution to the crisis must be predicated on "our desire that Libya's unity and territorial integrity be respected as well as the rejection of any kind of foreign military intervention." [Xuequan 2011] The role of AU's as pacific mediator is an indication of its willingness and desirability to amicably resolve disputes or crisis amongst members states in the continent.

African solution to African problems was effectively displayed by the African Union in Niger after the February 2010 military coup. The AU unambiguously condemned the coup plotters and suspended the country, pending the return to the status co which is the legitimate democratic government that was overthrown. Also the "African Union is finding its feet today, taking a lead in diplomatic efforts in Sudan and Cote d'Ivoire, and peacekeeping in Somalia and Darfur. [Perry 2011]

\section{Was African Union Ignored In Libyan Crisis?}

We noticed above how some of the efforts of the African Union to diplomatically resolve the crisis in Libya without plunging the country into outright war may have saved the country from the wanton destruction of lives and properties that was the consequence of invasion by Western Forces. The question here is was the African Union ignored in the solutions to the crisis in Libya? You would recall that the African Union Chairman (Jean Ping) said that "The African Union feels completely ignored by World bodies in the quest to restore peace in conflict ridden Libya... efforts by AU to intervene in the early days of the Libyan crisis were curtailed by the UN Security Council and since then the regional body has been left out of peace talks on Libya." [Gadugah 2011]. Jean Ping lamented that "Nobody talk to us; no body consult us ...Asked if the AU has been ignored in the UN, his answer was blunt: 'Totally, totally,' he said." [ibid]

The African Union (AU) is a regional international organization consisting of fifty three African states. It is a successor to the amalgamated African Economic Community (AEC) and the organization of African Unity (OAU). Launched in the Durban Summit of July, 2002 “...with the aim of developing and integrating Africa, the AU aims to assist Africa to transform into a prosperous and stable continent commanding more respect on the international stage.” [Madlala 2011]

The Constitutive Act of the African Union spells out fourteen objectives. The most significant and current are integration and sustenance of peace and security. Maintenance and sustenance of peace and security is the major prerogative of the Peace and Security Council. For the crisis in Libya the "African approach was based on a realistic appreciation of the perils of civil war in Libya and the shortcomings of forcible regime change." [Dewaal 2011]

At the wake of the crisis Western forces has acknowledged and recognized the fact that issues that border on the security of a region should carry the regional organization of such a region along. In the case of Libya the AU is the primary and most fundamental constituency to handle and resolve its disputes just as the EU is to France. The original plan was to follow the established and generally accepted due process of enough time for the regional bodies to mediate. "Western countries and NATO have initially insisted they will not intervene militarily in Libya without approval of regional organizations such as the Arab League and the AU and a UNSC clear mandate. However, references to AU's prior consent were later dropped..." [Sudan Tribune]

The question here is why was Africa ignored in her genuine security efforts? A major factor responsible for this stance is the ulterior motives of the invasion. Africa was ignored not just because they are completely bereft of ideas and solutions to the crisis but because Western powers have vested interest in the exploitation of Libya's oil. Even as the fighting and intervention were ongoing and not finalized, people representing the economic and corporate interest of the US and Europe have been gathering in Libya to cut their pound of flesh on the plunder. These Western powers according to O'Connor (2011) are "scrambling to secure 
their cut, above all of the North African state's enormous oil reserves-recently described by the US ambassador there as the Libyan "jewel in the crown."

This is better appreciated when we understand that Libya has the sixth largest oil reserves in the world. According to Smith (2011) "The Libya crisis was arguably initiated, covertly or otherwise, for profit making purposes. Being the country with the sixth largest oil reserves in the world." The whole idea of ignoring Africa was to "prepare for a direct imperialist takeover, they followed a well-worn path, vilifying the country's leader and promoting the idea that only outside intervention could save innocent civilians from a looming massacre." [Auken 2011]

Declaration of war on Libya has wantonly destroyed properties. This would eventually be rebuilt at very great cost to the country by the new regime. According to Bokor (2011) "We can tell from the massive destruction of those 20 or more strategic installations that the billions of dollars spent by Libya on those installations have become dust." Spuriously, these wanton destructions are viewed by the invading forces as a destruction of the military arsenals of Gaddafi and his loyalist and discarded into the dustbin of irrelevant memories. This is erroneous because the properties destroyed belong to Libya and her people in totality.

The unveiling ulterior motives have attracted protest and criticism from around the world. The Arab League who initially supported the intervention because they did not fully understand the undertones eventually according to Bokor (2011) "bared its teeth against this excessive bombing, saying that it wanted protection for civilians, not this large-scale bombing of Libyan installations." Russia is also greatly opposed to the quest of Western forces to achieve their ulterior goals under ideological or philanthropic guises. A statement by the Foreign Ministry says "it is inadmissible for the aims of Resolution 1973 to change for the Coalition to go outside the mandate of that framework." (ibid)

United Nations Security Council Resolution 1973 was passed on March 17, 2011 to authorise a no-fly zone for the protection of civilians. Three AU members were part of the Security Council members who endorsed Resolution 1973. According to Chipaike (2011) "The fact that the three AU members in the UNSC voted for Resolution 1973 for the establishment of a no-fly zone and the consequent bombardment of Libya by NATO implies that the AU does not trust its own capacity to deal with conflicts of the magnitude in Libya." A regional organization like AU should be able to speak with one voice and have confidence in its ability despite mounting pressures from other regions. "Rather than acting decisively, the African Union (AU) cowered to pressures from the West and voted for U.N. Security Council Resolution 1973, which authorised military action in Libya." [Akonor 2011] Succumbing to the pressures by Western forces to vote for the passage of Resolution 1973 was a license for foreign intervention at any level and gross display of deficiency on African solutions for African problems. "By voting for Resolution 1973, the AU had shown its capitulation to Western pressure and in doing that it was unwittingly giving NATO the responsibility to deal with an African conflict." [ibid]

This should not be the case because NATO is an organization of its own and members of the African Union are not it members. The North Atlantic Treaty Organisation (NATO) was created on April 4, 1949, when representatives of twelve nations signed the North Atlantic Treaty in Washington - most importantly to consider the fact that "armed attack against one or more of them in Europe or North America is an attack against them all". The scope is clearly defined and there was no attack on Europe or North America. The AU has all provisions for peace making and enforcement. Accordingly Akonor noted that "Article $4(\mathrm{~h})$ of the AU act gives the AU the right to intervene forcibly in one of its member states with regards to war crimes, genocide and crimes against humanity". Assuming members of the Warsaw Pact (another collective defence group), carried out the bombardments on Libya in the magnitude they did, it should have been widely criticized by the West.

The irony of it all is that Resolution 1973 is robbing Peter to pay Paul. Gaddafi tried to defend his regime by suppressing revolts while Resolution 1973 empowers NATO to support his opponents and fight the proponents of Gaddafi and his regime. "By passing Resolution (1973), the UNSC gave NATO-deliberately or unwittingly- the right to aid rebels in their fight against Gaddafi under the Responsibility to protect (R2P) facade." [Chipaike 2011]

Additionally the declaration of war on Libya caused wide scale destruction of monumental properties and loss of human lives. The destroyed properties belong to the people of Libya in general. Before the war Libya was the most developed state in the whole of Africa, using United Nations Development Report indexes. "Libya has the highest development on the continent in terms of education, health and wealth. According to last year's U.N. human development report, Libya even outperformed Brazil, Russia, India, China and South Africa - the BRICS group of fastest growing economies." [Akonor 2011] The inconsiderate declaration of war on Libya, without the consent of the African Union have left all these developments in ruins.

Another likely reason why Africa was ignored is because it is weak militarily and financially. Most African states are completely dependent on Western powers for survival in every ramification. This dependency according to Wangari (2011) "hampers the organization's effectiveness in many ways. It constrains its ability to have an independent voice and could account for the AU's relative silence on the situation in Libya..." This is coupled with the fact that the AU's aim of having a single integrated defense force is still on the drawing board 
stage. There is no handy standing army designed for the purpose of peace keeping or peace enforcement. The "AU has neither an army nor a peacekeeping force, so it cannot intervene militarily to protect citizens. It also has relatively little influence on national armies." [ibid] It was for these reasons that Western forces relegated the much acclaimed and internationally acceptable diplomacy that was recommended by the African Union but choose to declare war on Libya to pave way for the actualization of their ulterior goals.

\section{Conclusion And Recommendations}

The invasion of Libya codenamed Operation Odyssey Dawn by the Allied forces should have been the last recourse after extensive diplomatic efforts which normally take time. Enough time was not allowed the African Union to pursue its diplomatic efforts. The Libyan crisis started in mid February 2011 as part of the Arab Spring Uprisings and by mid March (precisely $19^{\text {th }}$ March 2011 - which is barely 1 month) Resolution 1973 was passed to enforce a no-fly zone and protect Libyan civilians. This resolution was eventually used by the Allied forces to declare war on Libya.

The roadmap of Africa to diplomatically mediate the crisis was a better option. The roadmap presented issues like: immediate cessation of all hostilities; cooperation of the concerned Libyan authorities to facilitate the timely delivery of humanitarian assistance to needy populations; protection of foreign nationals, including the African migrant workers living in Libya; and dialogue between the Libyan parties and establishment of a consensual and inclusive transitional government. A panel was constituted to oversee the accomplishment of these goals. The panel was a formidable diplomatic force because the personalities wielded the required clout for a negotiated settlement devoid of war with all its complexities, tremendous casualties and massive destruction of properties.

The diplomacy of the African Union was the better option because in contemporary international relations, nations politely engage in diplomacy and eschew aggression or outright war on other states as reciprocity is expected. More so, war has been prohibited as an instrument of foreign policy as evident in the Kellogg-Briand Pact and the United Nations Charter.

It recommends that in tandem with Article 33 of the United Nations Charter that parties to a dispute that might endanger peace should first seek a resolution through negotiation, inquiry, mediation, conciliation, arbitration, judicial settlement, resort to regional agencies or arrangements, or other peaceful means of their choice. Brute force or savage declaration of war is a barbaric act that is alien to the contemporary international order and age of globalization where diplomacy and corporation between nations is the trend.

The procedure for settling disputes or crisis should allow enough time. Enough time should have been given to weigh the success or failure of the normal diplomacy and to progressively intensify intervention through coercive diplomacy if the conventional diplomacy fails. A combination of diplomacy and coercive diplomacy of the international community as a whole would have peaceful resolved the crisis without declaration of war.

Despite the great prospects and good diplomatic initiatives of the African Union, there is still room for improvement. The study recommends that the African Union should work towards having a collective Military Force for peace keeping and peace enforcement in the African continent. The AU's aim of having a single integrated defense force is still on the drawing board stage. There is no handy standing army designed for the purpose of peace keeping or peace enforcement.

Africa should also strive to be more united in fact and deed. Divisive tendencies should be renounced. The African Union should learn to be more outspoken and also speak with one voice when dealing with the holistic international community. The presentation of the African Union was apparently not in tandem with the three African states in the United Nations Security Council because while the three African states voted in favour of UNSC Resolution 1973; the African Union was opposed to foreign intervention and set up a high powered delegation to mediate the crisis in Libya. The three African states signed despite the overt signals of Russia, China, Brazil, Germany and India who abstained in the signing of Resolution 1973 which was the caveat on which war was declared on Libya. It is only when there are no internal divisions whether by pressure or otherwise that the opinion or decisions of the African Union (AU) can be respected and complied.

The AU should also be more proactive and wake up to its responsibilities before the infiltration of foreign forces or external intervention. Apparently the AU did not take action on time in the Arab Spring Uprisings generally.

Power transition mechanism like government of national unity and such power sharing formulas to make peace between the government in power and opposition forces should be reviewed. The arrangement should be prudently and judiciously weighed by the AU before arriving at decisions. The idea of taken sides with incumbent governments, when the opposition forces are overwhelming in control, after the due process of elections, as was the case in Côte d'Ivoire and Zimbabwe should be reviewed. 
The idea of setting up a high powered delegation to mediate the crisis is highly commendable. It is however recommended that subsequent delegations should consist of highly respected African leaders of proven integrity and high repute. This should take into cognizance the regions in question and popularity of the leader.

\section{References}

[1] Cogan James (2011, Jul 16), As military operations stall, US recognises Libyan rebels, Published by the International Committee of the Fourth International

[2] Shah, A. (2011, April 5), Crisis in Libya. Global issues, in Kamwanyah Ndumba J. (2011, Aug 24) The African Union's Indifference on Libya, Foreign Policy Association

[3] Normand Roger (2003, Mar), War in Iraq - Unequivocally Illegal, Information Clearing House: Daily News Headlines Digest

[4] Gadugah Nathan (2011, Mar), AU Totally Ignored by UN on Libya, The Ticklish, Retrieved from http://theticklish.blogspot.com/2011/03/au-totally-ignored-by-un-on-libya.html [date accessed Jan 24, 2013]

[5] Ghosh Peu (2009), International Relations, PHI Learning Private Limited, New Delhi

[6] Starke J. G. (1983), An Introduction to International Law, Butterworth and Co Publishers, London

[7] Umozurike U. O. (2001), Introduction to International Law, Spectrum Books Limited, Ibadan

[8] Harold Nicolson "Diplomacy" in Hamilton Keith and Langhorne Richard (1998) The Practice of Diplomacy: Its Evolution, Theory and Administration. Routledge, London

[9] Hunt Peter (2008), Review of Raaflaub's War and Peace in the Ancient World, University of Colorado

[10] Raaflaub K. A. (2007), War and Peace in the Ancient World, Oxford: Blackwell Press

[11] Clausewitz Karl Von (1976), On War, Translation by Michael Howard and Peter Paret, Princeton, N. J.: Princeton University Press, Princeton

[12] Arend Anthony Clark and Beck Robert J. (1993), International Law and the use of force: Beyond the UN Charter paradigm, Routledge London and New York

[13] George Alexander L. (1991) Forceful Persuasion: Coercive Diplomacy as an Alternative to War, United States Institute of Peace Press, Washington DC

[14] George Alexander L (1994), The Limits of Coercive Diplomacy, in Phil Williams et al (ed) Classic Readings of International Relations, Harcourt Brace \& Company

[15] Lake Daniel R (2001), Military Force, Coercion and Domestic Politics: The Lessons of Kosovo, Paper presented at the 2001 Annual Convention of the International Studies Association, Washington DC

[16] Art Robert J and Cronin Patrick M (2003), The United States and Coercive Diplomacy, United States Institute of Peace Press. Washington DC

[17] Tarzi S. M. (2006), Coercion as a Prelude to War: Failure of US Coercive Diplomacy in the $1990-1991$ Gulf Crisis and Lessons for US Policy, Bradley University Press

[18] O'Connor Patrick (2011, Oct 4), NATO assault on Sirte inflicts more Libyan civilian casualties, Published by the International Committee of the Fourth International

[19] Dewaal Alex (2011, Dec), The African Union And The Libyan Crisis Of 2011, Reinventing Peace - World Peace Foundation, @http://sites.tufts.edu/ reinventingpeace/2012/ 12/19/the-african -union-and-the-libya-conflict-of-2011/ [date accessed Nov 18, 2012]

[20] Madlala David (2011, Jun 16), Resistance in times of crisis: The African Union's opposition to foreign intervention, Consultancy African Intelligence, @ http://www.consultancyafrica.com/ index.php? [date accessed Dec 15, 2012]

[21] Jean Ping (2011, Dec 15) African Union role in the Libyan crisis, Pambazuka, @ http://pambazuka.org/en/category/aumonitor/78691, [date accessed Nov 10, 2012]

[22] Burns John F. (2011, May 30), Qaddafi and Zuma meet but no agreement, New York Times in Madlala David (2011, Jun 16), Resistance in times of crisis: The African Union's opposition to foreign intervention. Consultancy African Intelligence.

[23] Chipaike Ronald (2012, Apr), The Libya Crisis: The Militarisation of the New Scramble and More, International Journal of Humanities and Social Science Vol. 2 No. 8

[24] Xuequan Mu (2011), AU panel says opposed to foreign military intervention in Libya, in Madlala David (2011, Jun 16), Resistance in times of crisis: The African Union's opposition to foreign intervention, Consultancy African Intelligence

[25] Abati Reuben (2011 Mar, 27), African Union and The Libyan Endgame, Nigerian Village Square

[26] Perry Alex (2011, Feb 26) Africa's Feeble Response to Libya, Time World http://world.time.com/2011/02/26/africas-feeblerespond-to-libya/print/ [date accessed Nov 30, 2012]

[27] Sudan Tribune (2011, March 18), AU's opposition to military intervention in Libya ignored by UNSC, Obama @ http://www.sudantribune.com/spip. php? article38332 [date accessed Nov 22, 2012]

[28] Smith, P. (2011, October), Probe Libya's fire sale, The Africa Report, in Madlala David (2011, Jun 16), Resistance in times of crisis: The African Union's opposition to foreign intervention, Consultancy African Intelligence.

[29] Auken Bill Van (2011 Oct, 21), US and NATO murder Muammar Gaddafi, Published by the International Committee of the Fourth International

[30] Bokor Michael J. K. (2011, Mar 20), Democracy for Libya - A hard road to travel, @ http://www.modernghana.com/ news/321104/1/ democracy-for-libyaa-hard-road-to-travel.html [date accessed Nov 22, 2012]

[31] Akonor Kwame (2011, June 27), The African Union's mistake of policy and principle, Inter Press Service. In Chipaike Ronald (2012, Apr) The Libya Crisis: The Militarisation of the New Scramble and More, International Journal of Humanities and Social Science Vol. 2 No. 8

[32] Wangari Maathi (2011, Mar 20), AU not making itself heard on the recent troubles of North Africa, Sunday Times, 20 March 2011, http://www.timeslive.co.za. [date accessed Jan 28, 2012] 